\title{
Mongolian Rural Youth Participation in the Politics: Research Comparative Analysis for Age Group for 18-45
}

\author{
Khatanbold Oidov ${ }^{1, *}$, Tserennadmid Chuluunbaatar ${ }^{2}$ \\ ${ }^{1}$ Department of the Political Science-Legal Studies, Institute of Philosophy, Mongolian Academy of Sciences, Mongolia \\ ${ }^{2}$ Department of the Third Neighbour Policy and Research, Institute of International Relations, \\ Mongolian Academy of Sciences, Mongolia
}

Copyright $\mathrm{C} 2018$ by authors, all rights reserved. Authors agree that this article remains permanently open access under the terms of the Creative Commons Attribution License 4.0 International License

\begin{abstract}
The paper attempts to make an analysis on the rural youth perception in the political activeness and motivations in the governing decisions. Especially, we investigated by the current status of education in the rural citizens in the following prospects of a/ educational status, b/ working positions, c/ social status, d/ political interests, e/ detachment to the politics, f/its reasons and social membership etc. The paper also reviews data on changes and prospects between rural youth under the age groups i.e. 18-24, 25-34, and 35-45. In accordance with analysis that comparatively with youth age classification and political interests, shown pre or upper youth ages responded that they are interested in politics and making new steps to change the social situation. Even though, youth who are aging up to that age group would like to participate in governing decisions with their activeness and motivations to reach their voices of freedom. In regard to above mentioned comparative analysis, the calculation of the political interests, detachment to politics, social membership and other circumstances towards political activeness and motivations of youth living in rural area. Such as youth level and types of profession, social membership or status are mostly dependent upon youth's social positions. Respectively, authors attempted to conduct a comparative data analysis on the series of researches on youth political participation and their activeness, motivations in the current socio-political orientations and trends of youth social responsibilities and accountabilities. The paper has simply used main data bases on sociological survey data on "Rural lifestyles" which was conducted in Dundgobi, Sukhbaatar, Arkhangai, Selenge and Bayan-Ulgii aimags in 2015-2016 by the Department of Sociology and Social Psychology at the Institute of Philosophy of Mongolian Academy of Sciences The rural area is divided into three levels of administrative units namely aimag (provincial center) soum center (the second smallest administrative unit in rural provinces),
\end{abstract}

countryside or bag (the smallest administrative unit in rural areas) distant from soum center of afore mentioned aimags.

Keywords Rural Youth, Political Participation, Political System, Election, Government and Democracy

\section{Rationale for Identifying Political Participation and Activity of Youth}

Political participation simply means an action taken by a citizen to influence the outcome of the development of political system, institutions and political decision making. According to American Politicians S. Verba and N.Ni. Participation includes "acts that aim at influencing the government, either by affecting the choice of government personnel or by affecting the choices made by government personnel"[1]. Participation thus includes voting, contacting elected representatives, participating in campaigns, etc. Furthermore, political participation can be classfied as an active and inactive participation, while it also can be further divided its participation method. In particular, political activity is about participation of social subjects in political system, for instance, initiatives and attempts made by citizens on influencing decision making process at public organizations. In order to create democratic political process and system, it is important to enable political participation of citizens as broad as possible.

There are different types of citizen's participation in political activities and it is generally divided into two different categories. The first category includes participation of citizen in election process which is the most common type of participation [2]. In this manner, citizens' participation, in particular social activeness of youth is an important area to discuss and explore in 
detailed, despite the number of political agenda and programme towards youth development, implementation status is not sufficient, therefore youth participation in political process has to be promoted through nationwide policy. Major results and conclusions of surveys conducted at national and international level in this field has been summarized below and more detailed information is described in related sections of this article.

In this section, it has been aimed to explore the current situation of the rural youth political participation based on initial data collected through sociological survey which has been conducted in Arkhangai, Bayan-Ulgii, Dundgovi, Sukhbaatar and Selenge aimag centers, on "Rural lifestyle" under the framework of main research theme of the Institute of Philosopy in 2015-2016. This article also aims to examines the main findings and conclusions on rural youth participation in politics in general, developed as part of national and international surveys on political participation of youth, in particular (i) in-depth analysis on survey data; (ii) main observations made on political interest and activity of rural youth; (iii) attitudes and perspectives of rural youth on political activities; (iv) main projections and conclusions.

\section{Data Analysis on Survey on Youth Participation in Politics}

In order to conduct in-depth analysis on age and sex structure of the surveyed youth, it is important to see the age and sex structure of the total population at national level. Population pyramid of Mongolian population covering period of 2014-2030 is shown below. As it can be seen from below pyramid, growth of Mongolian population has been decreased steadily starting from 2008 , which is partly caused by the low rate of birth in 1990s. However in 1991 , in total 70 thousand new borns were registered while in 1993 it has been decreased by 22.2 thousand new born only in 2 years and decreased to 47.8 thousand.
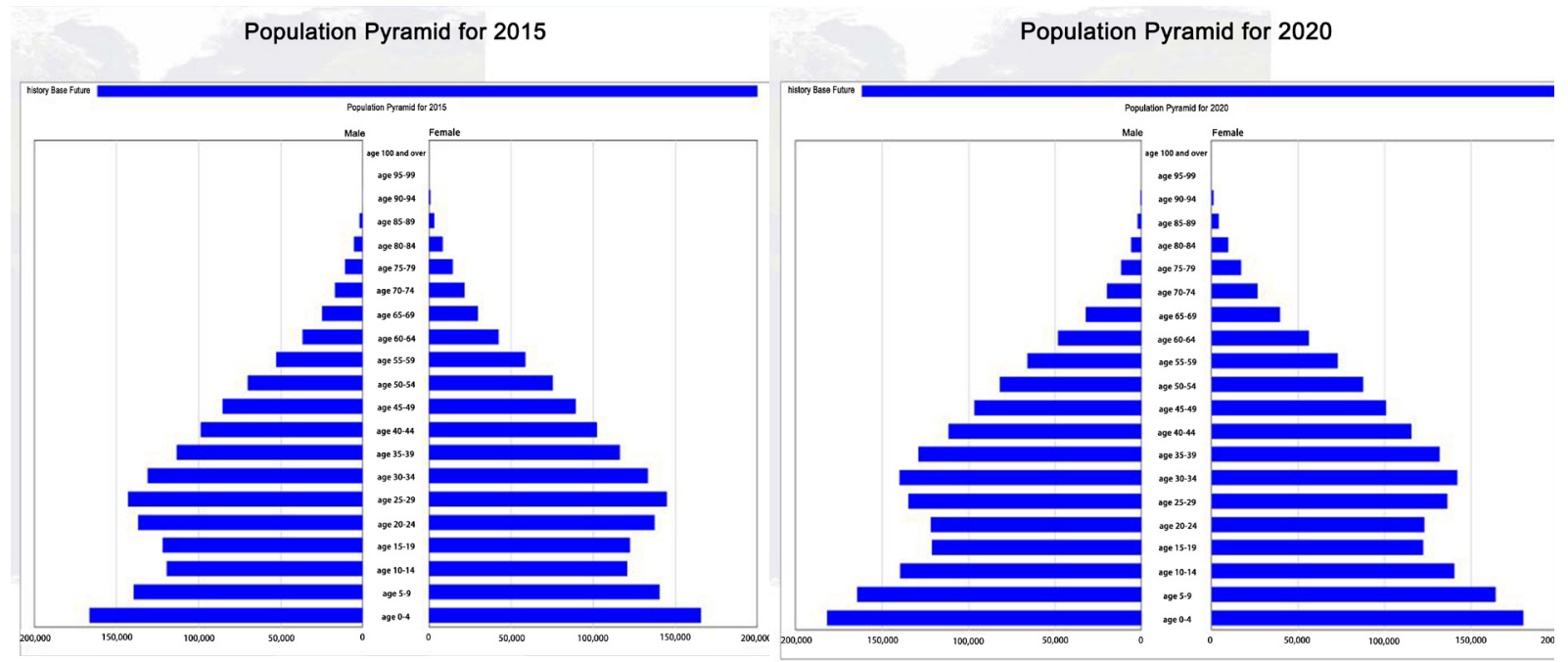

Population Pyramid for 2025

Population Pyramid for 2030
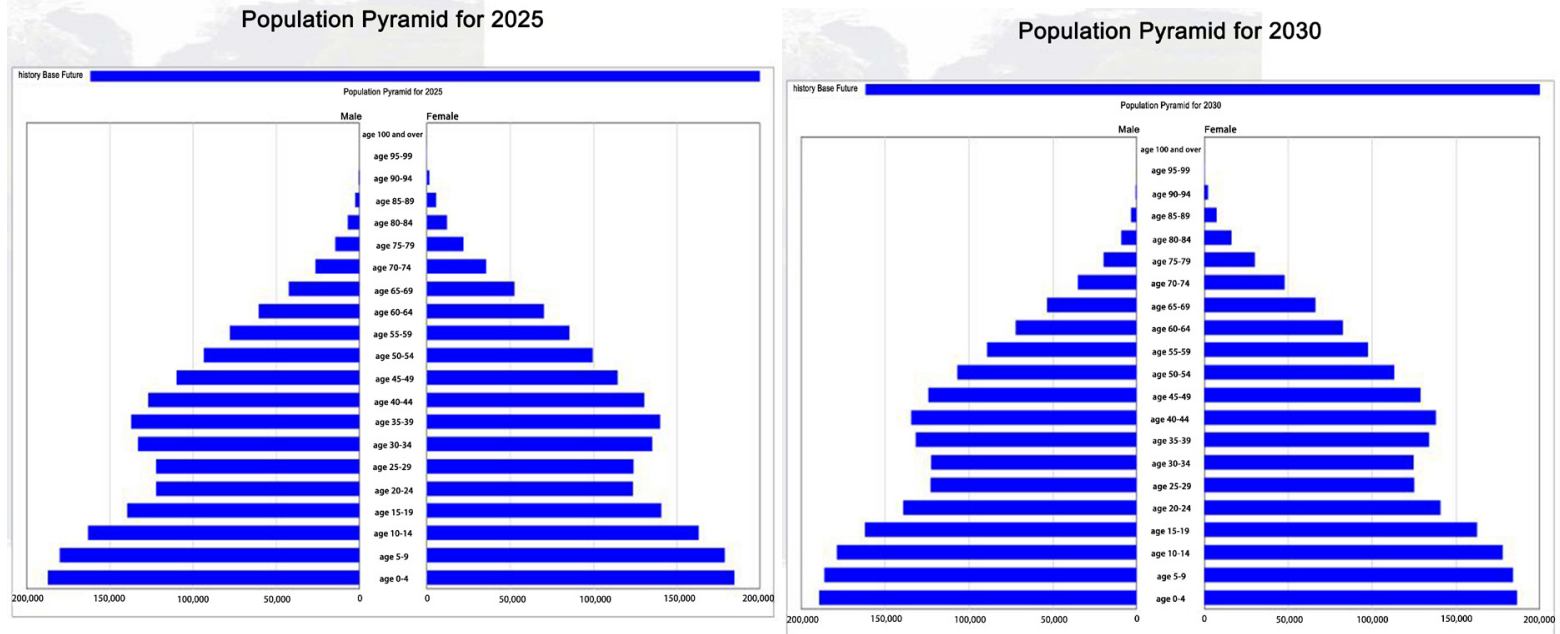

Figure 1. Pyramid of population growth in Mongolia (by 2015-2020) 
By the year of 2010, these newborn babies have reached at their reproductive ages which leads to the population window that has started in 2010. Target group of the survey was youth under age group 15-34 years old and they constituted 37.8 percent of total population in $2011,38.5$ percent in 2012, 37.1 percent in 2013 respectively. Population growth projection has estimated that youth will constitute from 36.4 percent to 28.6 percent between 2014 and 2030. In Mongolia, this rapid population growth or "the population window", this timeframe is the main factor that will shape the main characteristics and profile of Mongolian youth.

Age and sex structure of surveyed youth is classfied by their residential areas and sex ratio of youth aged between 18-24 residing in rural or remote areas was (male:female) 21:22 percent, youth under age of 25-34 (male:female) $30: 33$ percent. Sex structure of other age groups was similar to each other.

Educational level of rural youth under age of 18-24, 22 percent of total surveyed rural youth were females with primary education, 25 percent of total surveyed youth had received secondary education, while only 30 percent of them received tertiary education. Rural youth under age group 18-24, tend to prefer obtaining secondary education than tertiary or higher level education and tend to prefer living in their home communities. Sex ratio of age group under 25-34 with tertiary education was as following (male: female) 48:54 percent, with primary and secondary education (male: female) 29:27ratio, sex ratio of age group under 35-44 with tertiary (male: female) 19:11 percent. Out of these, 37 percent of total surveyed youth with higher education, 30 percent of total surveyed youth with secondary education and 30 percent of total surveyed youth with primary education lives in soum and aimag centers. 47 percent of total surveyed youth with higher education, 35 percent of total surveyed youth with secondary education and $\mathrm{n}$ lives in relatively remote areas. (Table 1). This number is mostly associated with the decreased number of school-drop out in rural areas as well as nomadic lifestyle and tradition. This is a clear indication that Mongolian youth tend to pay more attention on the quality and access to education of their children and wellbeing.

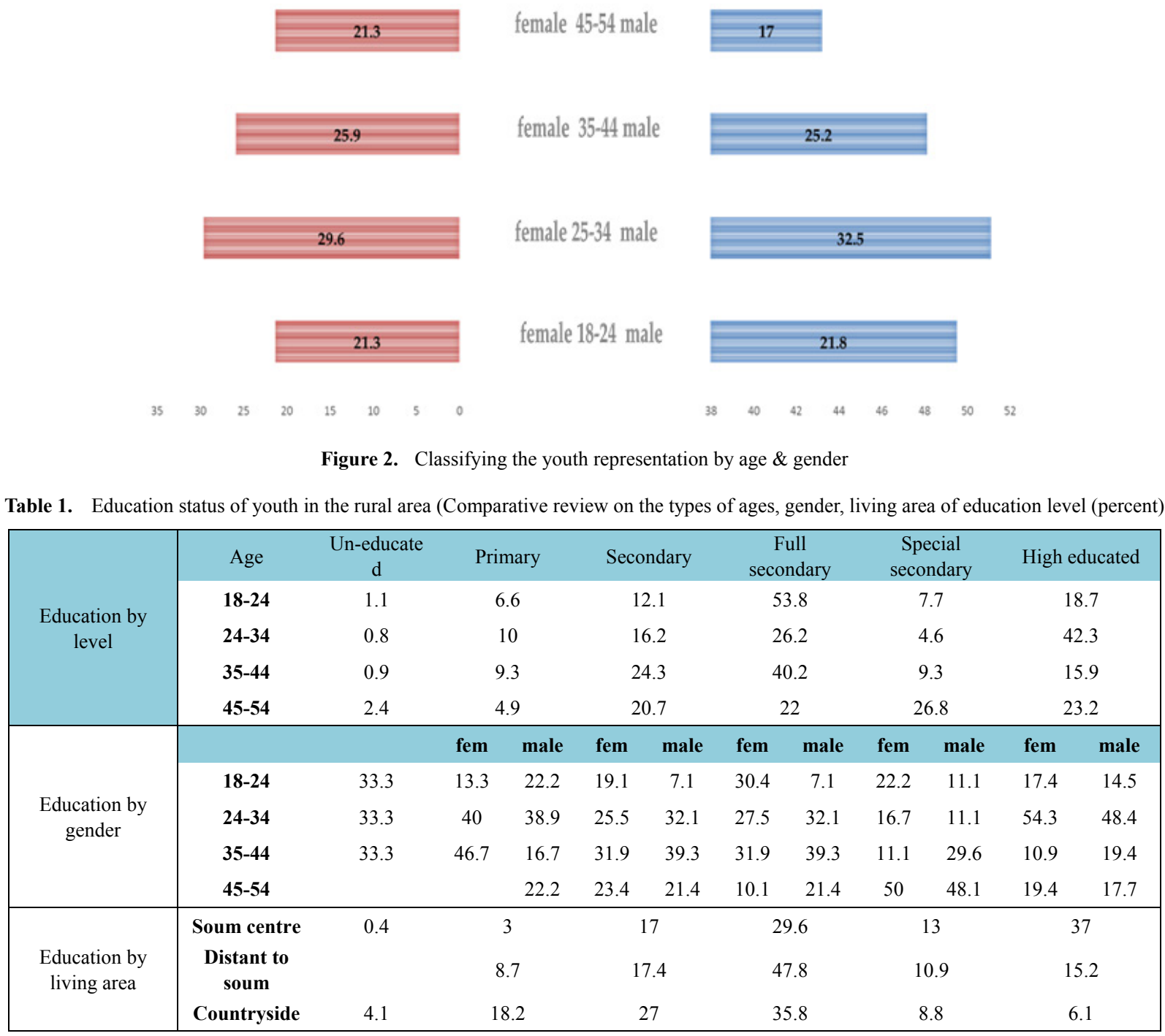

Table 1. Education status of youth in the rural area (Comparative review on the types of ages, gender, living area of education level (percent) 
Employment status of rural youth by age and sex is as shown below, 21 percent of total surveyed rural women engaged in trade and industry sector, 25 percent of them are housewives, 16 percent of them are engaged with some other sectors, while majority of the surveyed rural male youth is engaged with husbandry, vegetable planting and agricultural activities (Table 2).

73 percent of total surveyed male and 44 percent of total surveyed female youth have obtained professonal degrees such as lawyers, doctors etc while sex ratio of total employed youth in agricultural sector is balanced (male:female) 50:50 percent. 43 percent of total non-educated, 68 percent of surveyed youth with primary education, 38,5 percent of total surveyed youth with secondary education is now engaged with husbandry and farming. Based on these statistics, it can be said that the main source or tool for livelihood of rural youth is traditional livestock husbandry. 34 percent of total surveyed youth with higher education is employed at public organizations. These numbers shows that there is a need for improving quality of education provided to rural youth, to organize trainings and seminars to enhance their professional capacities.

In terms of membership to local organizations, 27 percent of total surveyed youth under age group 18-24 has obtained membership to local associations such as womens associations, 20 percent of total surveyed youth under age group 18-24 is member to local youth organization. 25 percent of total surveyed male youth and 21 percent of total surveyed female youth has replied that they are NOT involved with any type of political party or movement. 33 percent of total suyeved male youth under age of 25-34, 54 percent of total suyeved female youth are involved in activities organized by youth organizations. Among the age group 25-34, 36 percent of total male, 32 percent of total female have replied that they are not involved in any type of political party and movement. This rate shows that young adults are not eager to participate any political activity or be a member of political party or organization. However, among age group 35 and over, political participation and interest in political party or organizations is relatively higher (male: female) 50:36 percent, agricultural associations and cooperatives 40:41 percent (male versus female ratio). It shows that older they get, political participation and interest in political party or movement and attention to socio-economic and political matters increases among rural youth.

Table 2. Working status of youth in the rural area (Comparative review on ages, gender and education level (percent)

\begin{tabular}{|c|c|c|c|c|c|c|c|c|c|}
\hline \multirow{5}{*}{$\begin{array}{l}\text { Fmployment } \\
\text { (age, gender) }\end{array}$} & Age & Boss, owner & $\begin{array}{c}\text { Professionals } \\
\text { (doctor, lawyer) }\end{array}$ & Public servant & II erter & $\begin{array}{l}\text { famr worker \& } \\
\text { vegeta ble grocers }\end{array}$ & $\begin{array}{l}\text { Workers (other } \\
\text { professions) }\end{array}$ & $\begin{array}{l}\text { Jobless \& work } \\
\text { hunter }\end{array}$ & Ilousewife \\
\hline & 1824 & $12.5 \quad 2 \mathbf{1 . 4}$ & $\llbracket 13.3 \rrbracket 7.4$ & 】 13.3 || 4.1 & $\square 20.4 \quad \square 7.1$ & $3 \beta .3$ & $\rrbracket 10 \square 5.8$ & \10 \} $&{25} \\
{\hline} &{24-34} &{\begin{array}{|l|l|}43,8 & 28,6 \\
\end{array}} &{\begin{array}{|l|l|}73.3 & 44.4 \\
\end{array}} &{\left[\begin{array}{lll}6 & 6.7 & 40.8\end{array}\right.} &{\begin{array}{|l|l|}33.7 & 38.1 \\
\end{array}} &{\begin{array}{|l|l|}50 & 50 \\
\end{array}} &{\text { 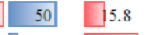 }} &{50 \square 5.8} &{ } \\
{\hline} &{35-44} &{\text { \12.5 } \quad 21.4} &{25.9} &{\begin{array}{l|l}\text { \13.3 } & 24.5\end{array}} &{\begin{array}{|l|l}32.7 & 26.2\end{array}} &{3 \beta .3} &{\begin{array}{lll}10 & 42.1\end{array}} &{\begin{array}{l|l}\| 10 & 421\end{array}} &{50} \\
{\hline} &{45-54} &{\begin{array}{ll}31.3 & 28.6\end{array}} &{\begin{array}{l|l}\square 13.3 & 22.2 \\
\end{array}} &{\begin{array}{lll}46.7 & 30.6\end{array}} &{\square=13.3 \quad 28.6} &{ } &{\begin{array}{lll}30 & 26.3\end{array}} &{\begin{array}{lll}\text { Bo } & 26.3\end{array}} &{25} \\
{\hline \multirow{7}{*}{\begin{array}{l}\text { Employment } \\
\text { (education level) }\end{array}}\begin{array} { l } { \text { Employment } } \\
{ \text { (education level) } } \end{array}} &{\text { Edu. level }} &{\text { Boss, owner }} &{\begin{array}{l}\text { Professionals } \\
\text { (doctor, lawyer) }\end{array}} &{\text { Public servant }} &{\text { Herter }} &{\begin{array}{l}\text { famr worker \& } \\
\text { vegetable grocers }\end{array}} &{\begin{array}{l}\text { Workers (other } \\
\text { professions) }\end{array}} &{\begin{array}{l}\text { Jobless \& wark } \\
\text { hunter }\end{array}} &{\text { Hou sewife }} \\
{\hline} &{\text { Uneducated }} &{0} &{0} &{13.3} &{42.9} &{0} &{28.6} &{0} &{286} \\
{\hline} &{\text { Primary }} &{8.5} &{12.8} &{ } &{683} &{2.4} &{7.3} &{7.3} &{7.3} \\
{\hline} &{\text { Secundary }} &{8.5} &{12.8} &{6.3} &{47.9} &{2.1} &{16} &{6.4} &{2.1} \\
{\hline} &{\begin{array}{l}\text { Full } \\
\text { secondary }\end{array}} &{7.1} &{16.7} &{21.9} &{38.5} &{1.9} &{5.1} &{6.4} &{1.3} \\
{\hline} &{\begin{array}{l}\text { Special } \\
\text { education }\end{array}} &{7.5} &{49.1} &{34.4} &{26.4} &{ } &{3.8} &{3.8} &{1.9} \\
{\hline} &{\begin{array}{l}\text { High } \\
\text { education }\end{array}} &{12.9} &{65.5} &{37.5} &{6} &{0.9} &{3.4} &{6} &{0.9} \\
$\hline
\end{tabular}

Table 3. Youth social status and membership Comparison to age, gender and education level (percent)

\begin{tabular}{|c|c|c|c|c|c|c|c|c|c|c|c|c|c|c|c|c|}
\hline \multirow{2}{*}{$\begin{array}{l}\text { Membership of } \\
\text { organizations Yes/No }\end{array}$} & \multicolumn{4}{|c|}{$18-24$} & \multicolumn{4}{|c|}{ 25-34 } & \multicolumn{4}{|c|}{$35-44$} & \multicolumn{4}{|c|}{$45-54$} \\
\hline & $\mathrm{Y}$ & $\mathrm{Y}$ & $\mathrm{N}$ & $\mathbf{N}$ & $\mathrm{Y}$ & $\mathrm{Y}$ & $\mathrm{N}$ & $\mathrm{N}$ & $\mathrm{Y}$ & $\mathrm{Y}$ & $\mathrm{N}$ & $\mathbf{N}$ & $\mathrm{Y}$ & $\mathrm{Y}$ & $\mathrm{N}$ & $\mathrm{N}$ \\
\hline Local community & 26.7 & 15.4 & 20.9 & 19.9 & 33.3 & 53.8 & 33.1 & 29.5 & 13.3 & 15.4 & 28.4 & 26.3 & 26.7 & 15.4 & 17.6 & 24.4 \\
\hline Trade Union & 25 & & 2 & 20.4 & 31.5 & 36.4 & 34 & 31.2 & 25 & 18.3 & 27 & 26.1 & 50 & 45.5 & 17.6 & 22.3 \\
\hline $\begin{array}{l}\text { Agricultural Association } \\
\text { and cooperation }\end{array}$ & 10.7 & 4.5 & 23.7 & 21.8 & 28.6 & 36.4 & 34.1 & 30.6 & 39.3 & 40.9 & & 23.8 & & & 7.8 & 24.5 \\
\hline Youth Fedeartion & 21.6 & 19.5 & 19.6 & 19.6 & 33.3 & 31.4 & 28.5 & 30.5 & 27.2 & 25.4 & 28.8 & 26.6 & & 8.7 & 19 & 25.3 \\
\hline $\begin{array}{l}\text { Political party and } \\
\text { movement }\end{array}$ & 21 & 19.5 & 25.2 & 20.9 & 17.9 & 27.3 & 36.3 & 31.6 & 50 & 36.4 & 22.2 & 24.7 & 28.6 & 36.4 & 16.3 & 2.8 \\
\hline Veteran's Association & 21.5 & 19.5 & 21.7 & 19.8 & 33.1 & 31.4 & 33.5 & 31.7 & 27 & 49.4 & 26.7 & 24.6 & 18.4 & 23.7 & 18 & 24 \\
\hline
\end{tabular}




\section{Observations Made on Interest in Politics by Rural Youth}

The Asia and Pacific region is home to over 45 percent of the world youth, amounting to around 700 million young people. Within this region, a number of disparities exist, South Asia is the most youthful subregion, it is home to 26 percent of the entire world youth, in South East Asia, youth constitute 18 percent of the population, in East Asia, 17 percent of the population qualifies as youth [3]. Several countries of Central Asia have been doing this in the context of enhancing youth participation in the development and decision-making processes for reaching the Millennium Development Goals and to resolve issues important to them, including health, education, employment and corruption. In many countries across the Asia-Pacific region, youth councils have been developed and Model United Nations entities have been established to encourage participation of young people. Similar situation is now being witnessed in Mongolia. Because, nearly 40 percent of total population of Mongolia is youth [4], it can be said that Mongolia is a country of young population. Compared to other social groups, Youth are the builders and owners of nation's future, who has an outstanding ability to adopt into new environment and to obtain the latest knowledge and new technologies than any other demographic group of the society. Youth are the builders and owners of nation's future, who has an outstanding ability to adopt into new environment and to obtain the latest knowledge and new technologies than any other demographic group of the society.

Youth should be both subject and object of social changes. In every period of the country`s development, youth are the main social group that will carry most significant features of social, economic and population development. Therefore, active participation of youth in social and political activities in every society will act as a significant domestic factor for the social development, as well as tool to develop personal and professional development of youth themselves. In other words, Political culture, constitution of social political ambition of youth should be considered within the actual context which is enchainment of negative and positive change in political life, advances and errors. Besides it should be taken into consideration social behavior, in particular ideology-political behavior, as well as impact of personal behavior of youth. If we look at social-political activity of youth from the genuine significance and essence side rather than formation side by numerical indicators, it would be clear that this has been hindered for many decades, limited by caste and single form in our country. For instance, according to the survey conducted among 2585 intellectuals in 1988, the significant portion of survey participants [5]* replied that:

- 45,8 percent has replied that they prefer knowledge related to their job and

- 17,7 percent answered that on gained qualification,
- 33,7 percent answered that knowledge on events in the country is more important

It was clear from this survey that large portion of survey participated intellectuals consider wide range of information on social-political life is not really necessary and information and knowledge of rural population on socio-economic status and development were relatively limited, since the majority of them were factory workers and herders [6].*

- 58.4 percent of total respondents,

- 76.7 percent of them were herders, could not provide any response on the current state of the country development.

- 80,6 percent of 129 members of the political party has replied that there is a conflict between capitalist countries.

Political and ideological knowledge of youth in previous society was relatively limited, in addition to this, one common ideology of Stalinist has been widely spread throughout the entire population which had a significant impact on formation of political knowledge and thoughts of youth. On the other hand, due to limited knowledge on political ideology and related disciplines, reactions to political actions or events by youth tend to be less-logical, based on emotional activity.

According to survey results, 24 percent of total surveyed youth watch TV news and newspaper several times a week, while 30 percent of them watch and read news related to politics and other government activities 1-2 times per week. 28 percent of total surveyed youth with secondary education watch and read news about politicts 1-2 times per week, while 31 percent of total surveyed youth with higher education pays attention to news related to politics. On other words, as the educational level of surveyed youth is higher, the frequency to pay attention on news about politics is increasing.

As it can be seen from the Figure 4, 46 percent of total surveyed youth under age group 18-24 does not pay any attention on news and information about politics, 30 percent of surveyed youth under age group 25-34 also do not pay any attention to news related to political development in the country. Contrarily, youth under older age group (35-44) tend to spend more time on receiving information about current state of socio-economic and political development. For instance, 37 percent of total surveyed people under age group 45-54 spend time to watch news about politics at least 2 times per week.

Limitation of thoughts, political consciousness, and spread of dogmatism definitely led to inactive and indolence generation of youth. In most cases, youth turned into inactive objects of decisions, guided by administrator or any activity that is organized and located in position of indulgence, obedient performer rather than being active subject to social relation and process of politics [7] $]^{*}$.

In 1991, at the beginning of the development of social 
reform and market relations, 65 percent of total surveyed participants have replied that Mongolia is now in wrong path of development, however this evaluation has been significantly decreased after one year, in April, 1992, 48 percent of total surveyed participants have replied that the development path that Mongolia has chosen is not correct. 14.3 percent of total respondents have replied that even though the current state of the socio-economic condition of the country is not good, there is still a chance to develop steadily over some time. 22.6 percent of total respondents have replied that the current state of the country is not good, there is no promising future and condition will get worse over the time. In other words, 1 of every three respondents have replied that they are hopeful, they expect this development path will bring prosperity to the country, while 1 of every five people have replied that they are not sure and still concerned, and only 1 of every 20 respondents have replied that this path is not the right path to follow. These statistics indicate that after certain period of time, social psychology that was strongly affected by the aggressive market competitiveness was finally settled down and adapted to the new social order and lifestyle [8].

As the beginning of social and political activity among society, political consciousness of younger generation has started to be raised approximately from middle of 1980 , they started to consider the environment that they have been living and working in, and current situation of overall society from very different angle than earlier period, from different point of view and assessment. From one side, democracy, social justice, hollow statement of political party's bureaucracy about sensual and spiritual, culture, official morale operation, from other side, poor life differences with promiscuous conflicts, challenges that reaching the top, had given strong force to activate social and political activity by youth and refreshed political consciousness of younger generation. This was a historical lessons learnt from past practice of ideology and political behavior among youth that is to be considered in the future.

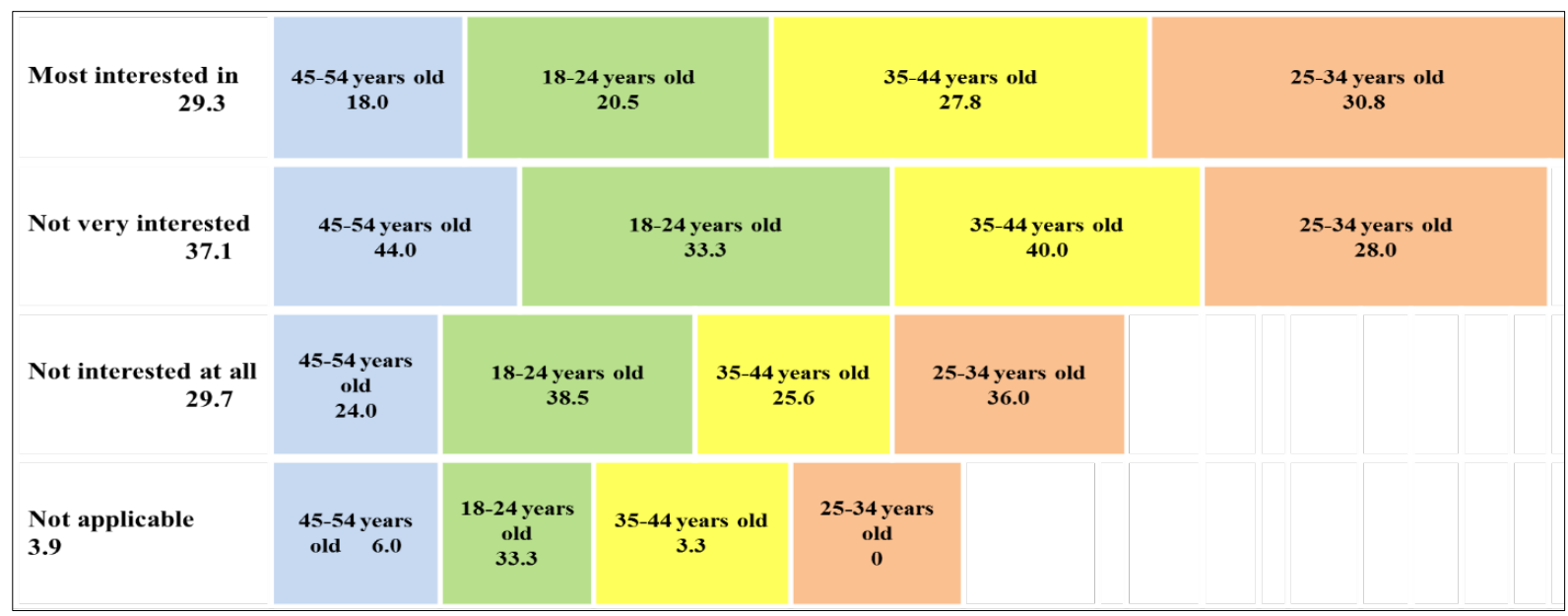

Figure 3. Youth political interests in the rural area (Comparison to age groups (percent)
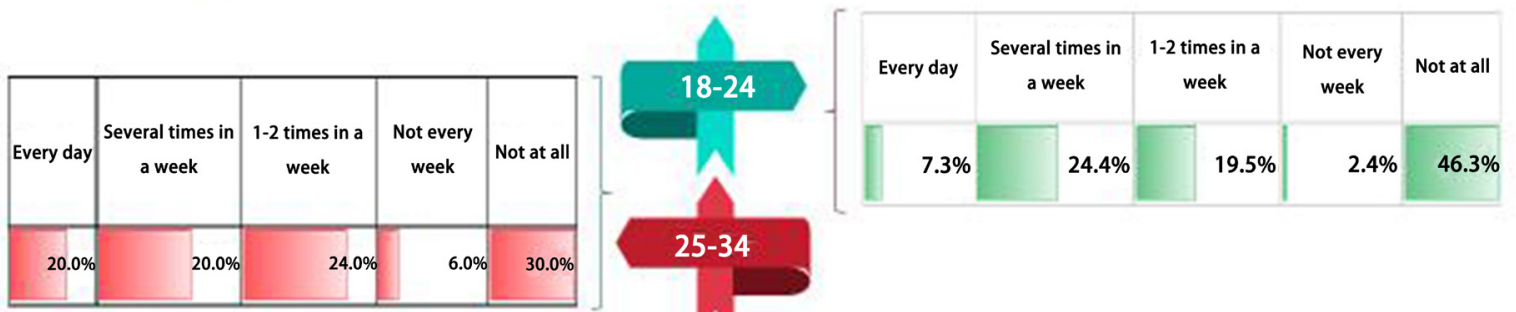

$25-34$
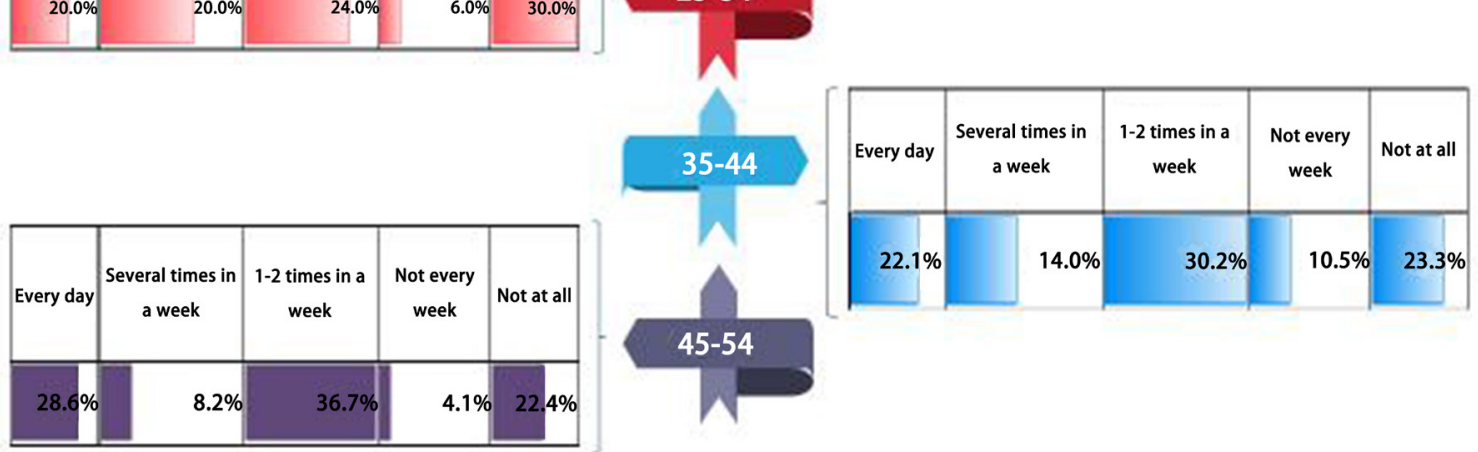

Figure 4. Rural youth - receiving information about the political and government news (Comparative review on age group and frequencies (percent) 


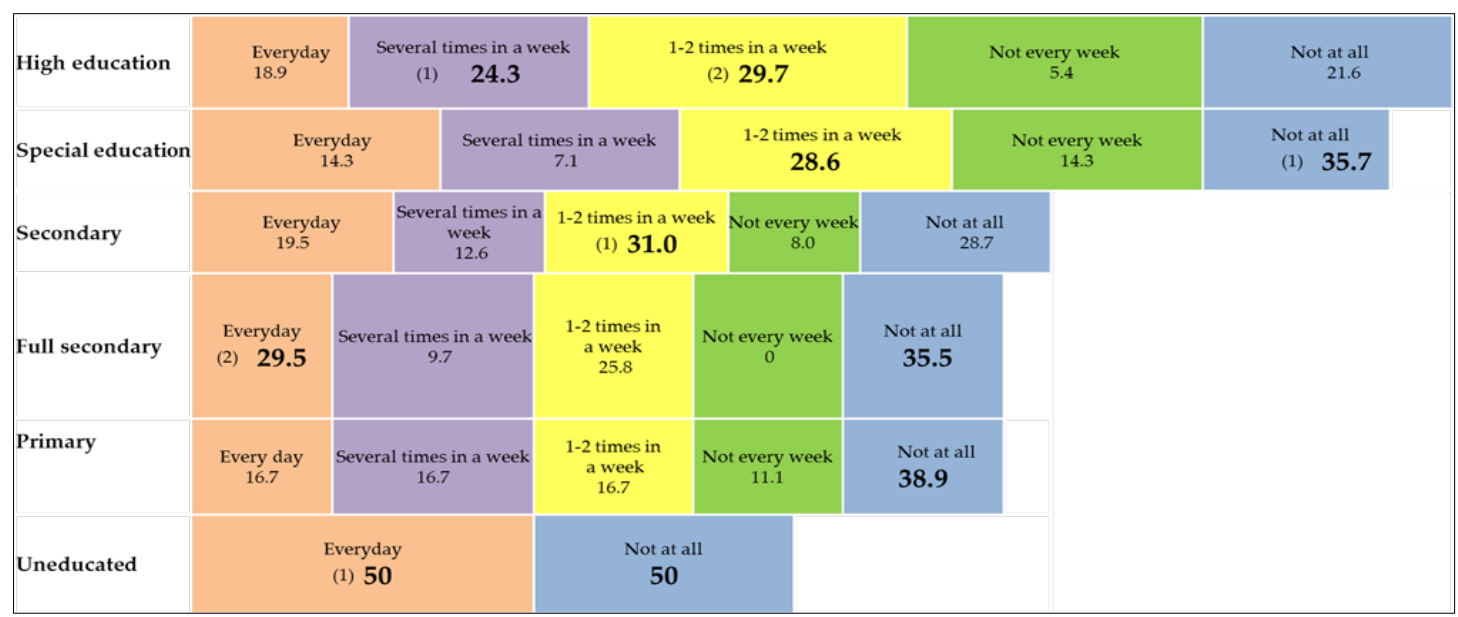

Figure 5. Rural youth - receiving information on political and government activities, by education level (percent)

37 percent of total surveyed rural youth not interested in politics, 29 percent of them have general interest in politics.

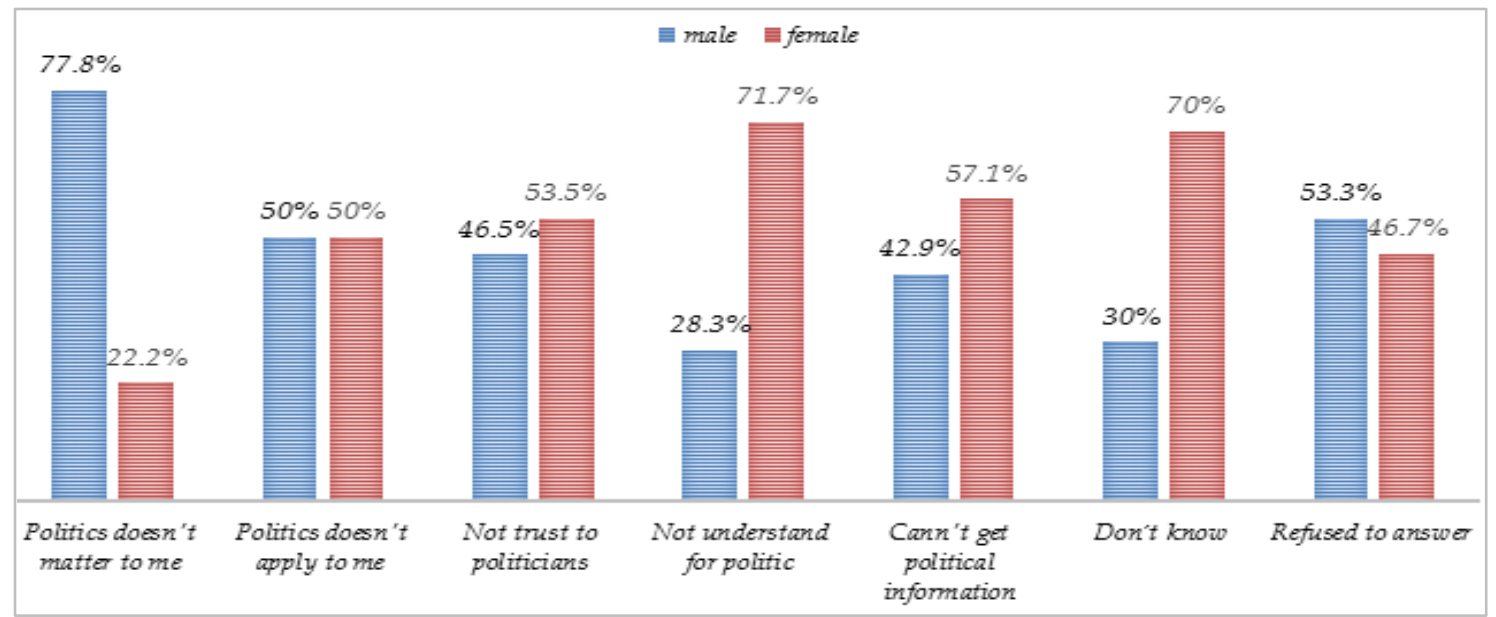

Figure 6. Reasons for not being interested in politics (Comparison by age group and gender, by percent)

The main reasons lying behind the low interest in politics by rural youth is as following: $78 \%$ percent of total male youth have replied that politics does not have anything to do with me, while only 22 percent of total female respondents have given same reason. Acts, speeches, actions made by politicians, programs and policies developed and implemented by politicians are not well received by rural youth. They do not have any trust to politicians, (male: female) 47:54 percent, I do not understand politics (male: female) 28:72 percent.

Table 4. Reasons for not being interested in politics (Comparison ty age group and education level, by percent)

\begin{tabular}{|c|c|c|c|c|c|c|c|c|c|c|c|}
\hline Reasons & \multirow{8}{*}{ 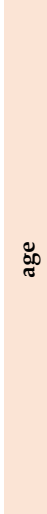 } & $18-24$ & $25-34$ & $35-44$ & $45-54$ & \multirow{8}{*}{ 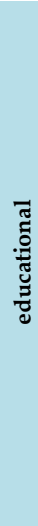 } & Primary & Secondary & $\begin{array}{c}\text { Full } \\
\text { secondary }\end{array}$ & $\begin{array}{c}\text { Special } \\
\text { secondary }\end{array}$ & $\begin{array}{c}\text { High } \\
\text { education }\end{array}$ \\
\hline $\begin{array}{l}\text { Politics does not matter } \\
\text { to me }\end{array}$ & & 33.3 & 16.7 & 33.3 & 16.7 & & 11.1 & 20 & 11.8 & & 6.8 \\
\hline $\begin{array}{l}\text { Politics does not apply to } \\
\text { me }\end{array}$ & & 22.2 & 16.7 & 44.4 & 16.7 & & & 8 & 13.2 & 20 & 11.4 \\
\hline $\begin{array}{l}\text { Not trust to the } \\
\text { politicians }\end{array}$ & & 14 & 23.3 & 39.5 & 23.3 & & 11.6 & 12 & 26.5 & 30 & 31.8 \\
\hline Don't understand politics & & 15.2 & 19.6 & 41.3 & 23.9 & & 13 & 44 & 22.1 & 20 & 27.3 \\
\hline $\begin{array}{l}\text { Can not get political } \\
\text { informations }\end{array}$ & & 28.6 & 14.3 & 14.3 & 42.9 & & 14.3 & 8 & 4.4 & & 2.3 \\
\hline DK & & 25 & 20 & 35 & 20 & & 10.5 & 8 & 7.4 & 20 & 15.9 \\
\hline Refused to answer & & 33.3 & 13.3 & 26.7 & 26.7 & & 6.7 & & 14.7 & 10 & 6.8 \\
\hline & & & & & & A & 11.2 & 16.6 & 14.3 & 20 & 14.6 \\
\hline
\end{tabular}


Based on above statistics, it can be said that there is a strong tendency among rural youth to be distant from politics, political activities. This situation is mainly associated with their age and educational level. For instance, 44 percent of total surveyed youth with secondary education and 27 percent of rural youth with higher education replied that they do not understand politics. 26 percent of rural youth with secondary education and 32 percent of rural youth with tertiary education have replied that they do not trust politicians. However, rural youth under age group 18-24 and 45-54 have no political knowledge, due to lack of access to political events, activities etc.

In 2012, UNDP and ABS has jointly conducted survey on "Southeast Asian youth and political participation, democratic governance and democracy"- and according to the survey results, majority of the youth living in this region preferred economic growth over the democracy $(66.8 \%$ and $28.2 \%)$. Similar to this, they think that the economic inequality is more important than protecting political freedom [9]. These numbers indicate that among young population of southeast Asian countries, democratic ideology is being strongly supported and there is no significant gender differences among the young population. Youth living in this region feel free to express their opinions, act freer than older generation when expressing their views on political activities and processes.

According to nation-wide survey results conducted in 2014 "Mongolian youth: Democracy, political activity and participation, knowledge and perception"(2014) [10]" knowledge and perception of politics among rural and urban youth was limited, they tend to see politics as the complex issue filled with lie and conflicts for power. If we look at this perception in depth, age, sex, marital status of any particular person has nothing to do with the political interest or participation of that particular person, instead employment status, educational level has more impact on their interest in politics. On the other hand, people with extensive knowledge in politics tend to be more educated. 64 percent of total surveyed youth were under the age group 24-29, 36 percent of them were under age 30-34. Relatively fewer respondents under age group 16-34 have replied that politics is important part of our lives and defines politics as their future, their choice etc. Majority of these respondents were relatively educated and have abundant living condition.

In last several years, it has been observed that political activity, interest in political process by citizens has been increased. This is mainly associated with the development of civil society organizations; they are more organized in delivering their voices to public organizations, decision making bodies, to organize demonstration in order to express their political will and demand. In this manner, political participation by citizens can be divided into three different categories such as active, moderate and inactive [11]. In this respect, developing countries that has chosen democratic society, tend to explore the political participation of citizens by evaluating the level of expression of views, level of participation in socio-economic and political activities, level of preferred political ideology, level of trust in public organizations.

\section{Perspectives of Rural Youth}

Major results and conclusions of surveys conducted in this field have been summarized below.

Satisfactory results on democratic process is mainly associated with the institionalized environment, its activity [12] and in this institutional activity, human capital, health condition and macro-economic results plays an important role. If there is high level of income equality, then there will be less satisfaction towards democracy [13]. Socio-Economic condition of the country has significant role in the assessment of democratic institutions, however financial and economic background of citizens also plays an important role, these wealthy people tend to see democracy positively, while less wealthy citizens tend to see democracy negatively since the democratic society has cause the loss of wealth or at least threat to wealth. In other words, any type of social change or reform will cause at certain point negative results, over the time. In order to prevent this negative impact or result, political activity and policy agenda developed by social institutions plays an important role [14].

East Asian Barometer (2008) survey has aimed to explore correlation between household income and democracy assessment. Through this approach, it has been discovered that compared to wealthier households, households with low and middle income are not satisfied with the policy implemented by the government. Because, social welfare and incentives provided by the government to poorer households is much lower than their expectations. Nowadays in democratic societies, re-allocation of income has become one of the major discussion points, according to them, amount of tax imposed to wealthy people should be higher, and the re-allocation of income should be implemented through social welfare allowances [15].

Survey on "Mongolian youth: Change in value and life goals" has been conducted in 2010 and it has aimed to compare the past and current state of youth and their life goals and values [16]. The most dynamic and active group of society is the youth [17], therefore, it is important to evaluate the changes in political views and ideology of youth.

76.9 percent of rural youth provided positive assessment on countries and their livelihood, they have expressed that they do have trust in political institutions. 39.2 percent of youth who have evaluated themselves as "capable of being involved in politics", do have trust in political institutions but the percentage share was 13.3 percent lower than other groups of surveyed youth. 


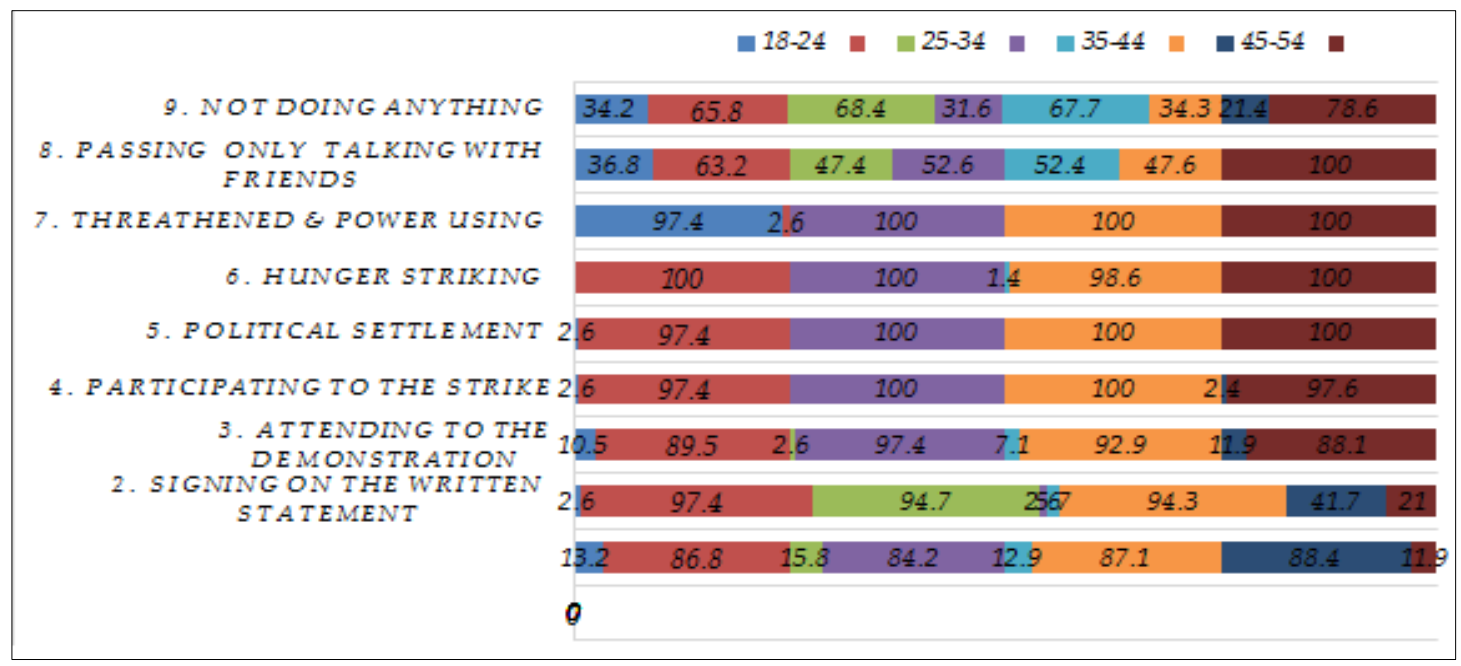

Figure 7. Rural youth disfavor expression to the political and government activities (Comparison to ages, perception and ranking, by percent)

\begin{tabular}{|c|c|c|c|c|c|c|c|}
\hline \multirow{9}{*}{ 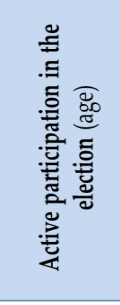 } & \multicolumn{3}{|c|}{ How often do you participate in the political election? } & 18-24 & 25-34 & 35-44 & 45-54 \\
\hline & \multicolumn{3}{|l|}{ Regularly involved and have voted } & 17.5 & 69.4 & 75.6 & 92.0 \\
\hline & \multicolumn{3}{|l|}{ Occasionally involved } & 12.5 & 26.5 & 18.9 & 6.0 \\
\hline & \multicolumn{3}{|c|}{ Not involved and voted by the election } & 15.0 & 2.0 & 3.3 & - \\
\hline & \multicolumn{3}{|l|}{ Have not chance to voting } & 10.0 & - & 2.2 & 2.0 \\
\hline & \multicolumn{3}{|l|}{ Not aged by 18 years old } & 42.5 & 2.0 & - & - \\
\hline & \multirow{2}{*}{\multicolumn{3}{|c|}{ Never voted }} & 2.5 & - & - & - \\
\hline & & & & 15.0 & 47.95 & 45.25 & 49.0 \\
\hline & Average percent & \multicolumn{2}{|c|}{ Negat } & 17.5 & 2.0 & 2-75 & \\
\hline \multirow{8}{*}{ 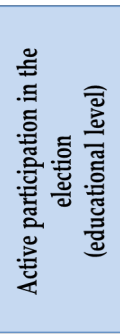 } & $\begin{array}{l}\text { How often do you participate in } \\
\text { the political election? }\end{array}$ & $\begin{array}{c}\text { Un- } \\
\text { educated }\end{array}$ & Primary & Secondary & $\begin{array}{c}\text { Full } \\
\text { secondary }\end{array}$ & $\begin{array}{l}\text { Special } \\
\text { secondary } \\
\text { education }\end{array}$ & $\begin{array}{c}\begin{array}{c}\text { High } \\
\text { education }\end{array} \\
\end{array}$ \\
\hline & $\begin{array}{l}\text { Regularly involved and have } \\
\text { voted }\end{array}$ & 50.0 & 68.4 & 84.8 & 54.1 & 85.7 & 72.0 \\
\hline & Occasionally involved & 50.0 & 15.8 & 9.1 & 15.3 & - & 24.0 \\
\hline & $\begin{array}{l}\text { Not involved and voted by the } \\
\text { election }\end{array}$ & - & 5.3 & - & 7.1 & 14.3 & 1.3 \\
\hline & $\begin{array}{l}\text { Have not chance to voting } \\
\text { Not aged by } 18 \text { years old }\end{array}$ & - & 5.3 & $\begin{array}{c}- \\
6.1\end{array}$ & $\begin{array}{r}5.9 \\
16.5\end{array}$ & - & $\begin{array}{l}1.3 \\
1.3\end{array}$ \\
\hline & Never voted & - & - & - & 1.2 & - & -2 \\
\hline & \multirow{2}{*}{ Average percent } & $\begin{array}{r}50.0 \\
0.0\end{array}$ & 42 & 46.95 & 34.7 & & 48.0 \\
\hline & & 0. & 15.9 & 6.1 & 7.6 & 14.3 & 1.3 \\
\hline
\end{tabular}

Table 5. Rural youth status in the electoral participation (Comparison by age group \& educational level, by percent)

Political views and ideology has become one of the important factors that define the understanding of the world by youth in general. It includes the general concept of the social regime that we are live in, political ideologies followed in practice, citizens assessment on that particular ideology, etc. On the other words, citizens and youth should not be participated in political activity forcefully or involuntarily, they must have a freedom NOT to participate in political activities However, if political participation by citizen is lower than it should be the quality of democracy will be reduced [18].

According to the survey results, the participation of rural youth in election is as following: 69 percent of total surveyed youth under age 25-34 have actively participated the election, while youth under age group 35-44 was higher than other group by 6.2 points. According to the principle of oligarchy of Aristotle [19] everyone has a right to be elected. Elections provide citizens some advantages such as the right to own a property, to receive an education etc. Percentage rate of rural youth with higher education level has actively participated in elections, in particular 16 points higher, compared to those who have secondary education.

When we compare above statistics with the statistics compiled during survey conducted by the Institute of Philosophy, MAS [20] in March 2016, three months prior to the election month, 53 percent of total surveyed rural youth have replied that they will participate in election, while only 5.8 percent of the surveyed youth have replied that they will not participate in election. 35 percent of the surveyed youth has replied that they have not made their final decision.

Political views and opinion on political activities by youth tend to be more mature, when they get older. When we look at the participation rate of election by age group, youth under older age group tends to actively participate elections. For instance, 48.8 percent of total surveyed youth under age group 18-24 expressed that they will participate in election, this rate is 4.6 point higher in youth under age group $25-30,5.5$ point higher among youth under age group 31-35. 


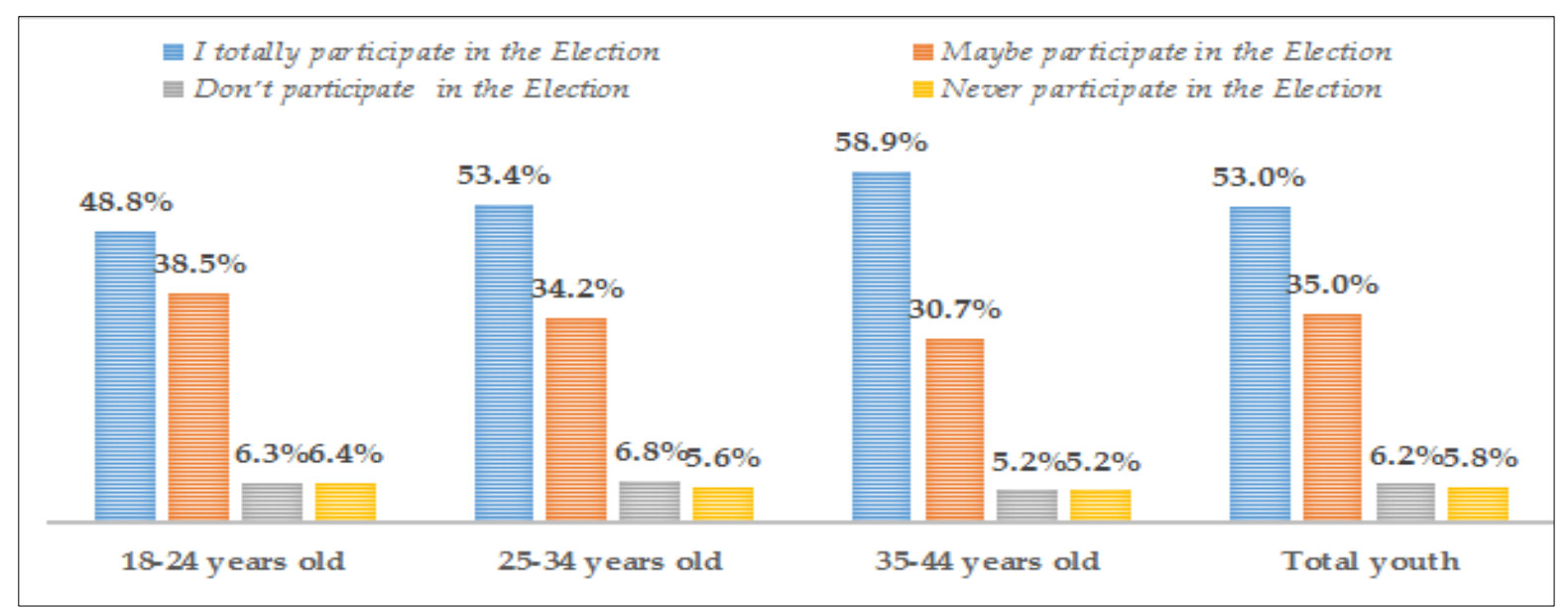

\begin{tabular}{|c|c|c|c|c|c|c|c|c|}
\hline ఏ్ర & \multicolumn{4}{|c|}{$\begin{array}{l}\text { Which is both of political party and federation feeling } \\
\text { the closest to you? }\end{array}$} & $18-24$ & 25-34 & $35-44$ & 45-54 \\
\hline$\sum_{\tilde{z}}^{\sum_{0}}$ & \multicolumn{4}{|c|}{ Democratic Party } & 37.5 & 32.7 & 22.2 & 40.8 \\
\hline$\frac{\pi}{\pi}$ & \multicolumn{4}{|c|}{ Mongolian People's Party } & 10.0 & 24.5 & 23.3 & 18.4 \\
\hline ฮี & \multicolumn{4}{|c|}{ Civil Will and Green Party } & 2.5 & - & - & - \\
\hline 恶 & \multicolumn{4}{|c|}{ Mongolian People's Revolutionary Party } & 7.5 & 8.2 & 3.3 & 4.1 \\
\hline$\cong$ & \multicolumn{4}{|c|}{ Mongolian National Democratic Party } & - & - & - & 4.1 \\
\hline 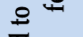 & \multicolumn{4}{|l|}{ But not both } & 42.5 & 34.7 & 51.1 & 32.7 \\
\hline & \multirow{2}{*}{\multicolumn{2}{|c|}{ Average percent }} & \multirow{2}{*}{\multicolumn{2}{|c|}{$\begin{array}{l}\text { Positive: +++ } \\
\text { Negative: --- }\end{array}$}} & 14.37 & 21.8 & 16.26 & 16.85 \\
\hline & & & & & 42.5 & 34.7 & 51.1 & 32.7 \\
\hline 䲶 & \multicolumn{2}{|c|}{$\begin{array}{l}\text { Which is both of political party and } \\
\text { federation feeling the closest to you? }\end{array}$} & $\begin{array}{l}\text { Un- } \\
\text { educated }\end{array}$ & Primary & Secondary & Full second & $\begin{array}{l}\text { Special } \\
\text { secondary } \\
\text { education }\end{array}$ & $\begin{array}{c}\text { High } \\
\text { education }\end{array}$ \\
\hline Е & \multicolumn{2}{|c|}{ Democratic Party } & 50.0 & 27.8 & 39.4 & 30.2 & 42.9 & 27.0 \\
\hline 도ำ & \multicolumn{2}{|c|}{ Mongolian People's Party } & - & 22.2 & 6.1 & 19.8 & 21.4 & 27.0 \\
\hline : ت्ञ & \multicolumn{2}{|c|}{ Civil Will and Green Party } & - & - & - & 1.2 & - & - \\
\hline 吾 & \multicolumn{2}{|c|}{$\begin{array}{l}\text { Mongolian People's Revolutionary } \\
\text { Party }\end{array}$} & - & 11.1 & 12.1 & 5.8 & - & 1.4 \\
\hline Еే & \multicolumn{2}{|c|}{ Mongolian National Democratic Party } & - & - & 3.0 & 1.2 & - & - \\
\hline 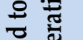 & \multicolumn{2}{|c|}{ But not both } & 50.0 & 38.9 & 39.4 & 41.9 & 35.7 & 44.6 \\
\hline 远 & \multirow{2}{*}{$\begin{array}{l}\text { Average } \\
\text { percent }\end{array}$} & Positive: +++ & 50.0 & 20.3 & 15.15 & 11.64 & 32.15 & 18.46 \\
\hline & & Negative: --- & 50.0 & 38.9 & 39.4 & 41.9 & 35.7 & 44.6 \\
\hline
\end{tabular}

Table 6. Rural youth attitudes to the Political Approaches (Comparison by age group, education level, by percent)

When we look at the political party affiliation of youth, older age group with higher level of education tend to have more sympathy on one particular party than younger age groups, as it can be seen from the Table 6 . In general, youth under age group 18-44 tend to support certain political parties as shown in the second table.

\section{Conclusions}

In last several years, it has been observed that political activity, interest in political process by citizens has been increased. This is mainly associated with the development of civil society organizations; they are more organized in delivering their voices to public organizations, decision making bodies, to organize demonstration in order to express their political will and demand [21]. In order to have impact on public policy, it is important to explore the essence of the issue, its potential results and factors. By evaluating and exploring the possibilities of expressing political views, right to be organized under union or associations, citizen's participation in political processes and assessment on the state of democracy can be achieved [22].

As a conclusion, public institutions, parliament, government agencies should pay attention on enhancing democratic principles in practice, by encouraging civil society organizations, non-governmental academic institutions, public media tools and channels and participation of private sector. Moreover, favorable legal environment that enables active participation of citizens in political activities shall be enhanced [23]. In order to increase the citizens participation and involvement in democratic process, in particular youth participation, it is important to conduct in-depth analysis the specific characteristics of that particular group of society.

In terms of rural youth, 25 percent of total surveyed youth have replied that the most challenging issue is the economic condition, which indicates the financial and economic barriers are the most common issue faced by youth. In other words, there are no employment opportunities for youth in rural areas, no financial support to start small businesses

As a conclusion, it can be said that through democratic 
institutions, an effective communication and cooperation between politicians and citizens shall be created or encouraged, boundaries established between politicians and citizens should be limited. On the other hand, in order to increase the political participation of citizens, elected officials and politicians should not only rely on their ultimate power of decision making, but also discussion and consultation with citizens should be carried out prior to final decision.

Citizens themselves should be educated and well informed prior to their participation in political process and activities. Accordingly, citizens also can act responsible for their own decisions, they will have more opportunities to express their political will and demands, will be able to join decision making processes which will gradually reduce the distance between politics and regular citizens.

Among to the rural youth, in order to comparing with the forms of disagreement to the political and government activities for rural youth age and perceptional ranking that has discovered by the following drawings. Accordingly, comparison to the forms of disagreement to the political and government activities that basis on the average evaluation of youths in the survey, 77 percent of 18-24 year olds, 85 percent of 25-34 year olds, 84 percent of 35-44 year olds and 80 percent of $45-54$ year olds are answered as not implying a negative assumption. But then, those aged youths above mentioned, they expressed that their views are positively related to the following prioritized assumptions, such as 22 percent of 18-24 year olds, 25-34 year olds 16 percent, $35-44$ years old 16.3 percent, and 18.3 percent of 45-54 year olds. ${ }^{*}$ It is a good example of a positive and peaceful solution to the problem-solving in the further challenges.

Political views and ideology has become one of the important factors that define the understanding of the world by youth in general. It includes the general concept of the social regime that we are live in, political ideologies followed in practice, citizens assessment on that particular ideology, etc. On the other words, citizens and youth should not be participated in political activity forcefully or involuntarily, they must have a freedom NOT to participate in political activities However, if political participation by citizen is lower than it should be the quality of democracy will be reduced.

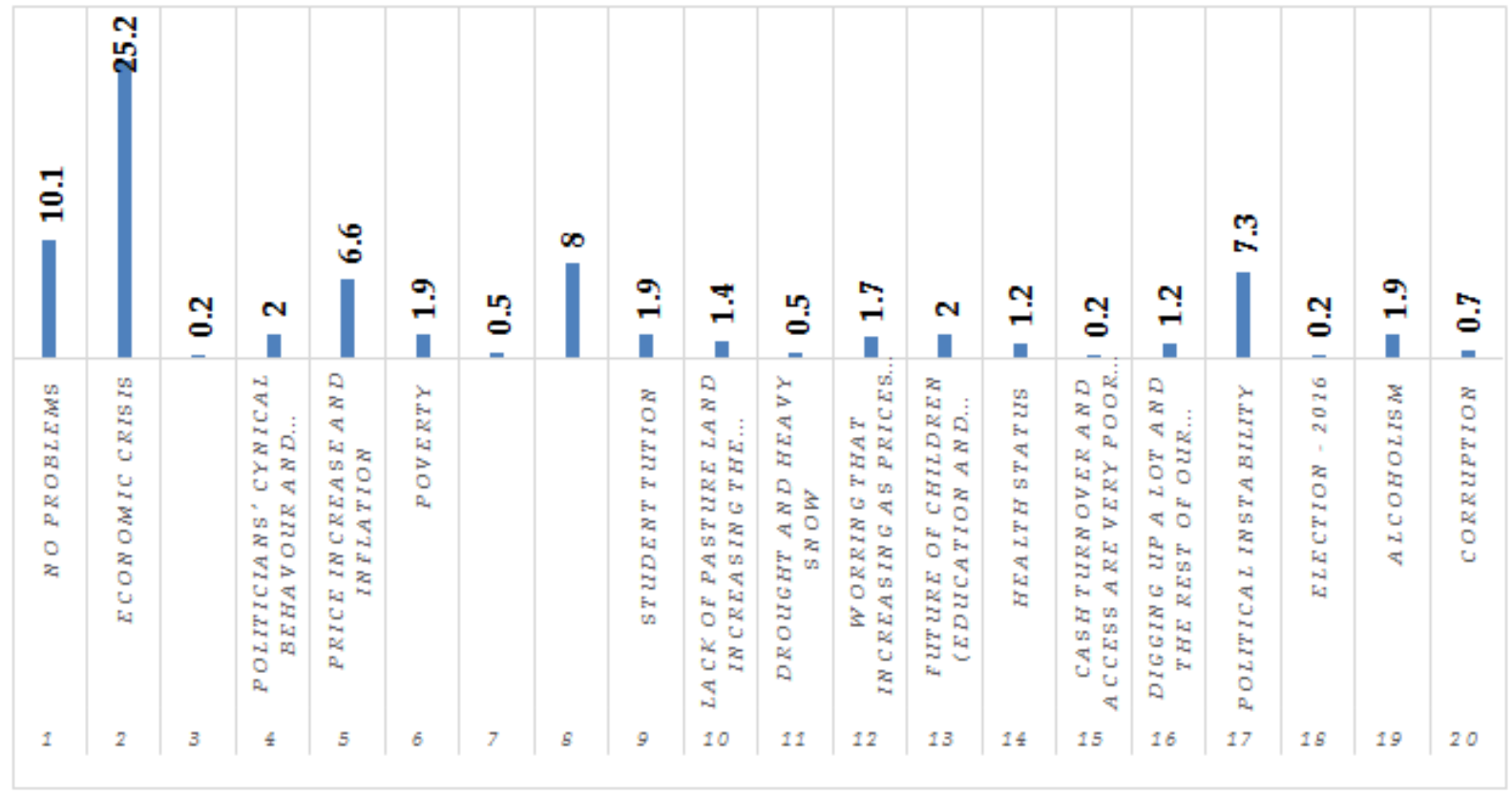

Figure 8. Problems and most challenging issues faced by rural youth (By ranking list of problems, percent) 


\section{REFERENCES}

[1] Tsanjid A. Political Sciences. UB, Mongolia, 2001. Admon LLC. p. 21

[2] Open society forum. Glossary of democratic governance and open society. UB, Mongolia. Admon LLC. 2006. p. 36

[3] UN. Available from http://social.un.org/youthyear/docs/ES CAPFinal5.pdf

[4] National Statistical Office. Bulletin of the National Statistical Office of Mongolia. UB, Mongolia. 2013. p. 45

[5] Institute of Philosophy and Sociology and Law. Current status of youth attitudes in the education, motivation and results. Sociological research report. Academic library at the Institute of Philosophy and Sociology, Mongolian Academy of Sciences. UB, Mongolia, 1988.

[6] Institute of Philosophy and Sociology and Law. Sociological survey among young people in the urban and rural area who involved by workers, herders. Academic library at the Institute of Philosophy and Sociology, Mongolian Academy of Sciences. UB, Mongolia, 1987.

[7] Institute of Philosophy and Sociology and Law, MAS. Between 1987-1988, the Institute of Philosophy were conducted sociological survey in accordance with targeting to research of youth education and activities in the social life.

[8] IPSL, MAS. The Mongolians in Sociological Studies. Compilation of research results. UB, Mongolia. 2007. pp. 118-119.

[9] Asian Barometer Survey Conference. [Panel VI: Paper 14]. Political Change, Youth and Democratic Citizenship in Cambodia and Malaysia. September 20-21, 2012 Taipei.

[10] Governance Research Team. IPSL, MAS. State Policy Analysis Institute (NGO). Sociological research titled on "Mongolian Youth: perception and understanding of democracy and political participation" in December 1, 2013 - March 25, 2014. UB, Mongolia.

[11] Gundsambuu Kh, Chuluunbaatar G. Mongolian youth in the threshold of XXI Century. UB, 1998. p. 67

[12] Asian barometer: Comparative studies on democracy development. Academy of Political Education. UB, Mongolia. 2008. p. 266

[13] Asian barometer: Comparative studies on democracy development. Academy of Political Education. UB, Mongolia. 2008. p. 266

[14] IPSL, MAS. The Mongolian in sociological study. Compilation of research results. Ulaanbaatar. 2007. p. 118

[15] APE. Asian barometer: Comparative studies on democracy development. UB, Mongolia. 2008. pp. 271-275

[16] IPSL, MAS. Sociological Research report on 'Changes in the living goals and values for the Mongolian youth'. UB, Mongolia. 2010
[17] Gundsambuu Kh, Chuluunbaatar G. Mongolian youth in the threshold of XXI Century. UB, 1998. p. 63

[18] State Great Khural (Parliament of Mongolia). Policy Analysis Centre. Policy analysis -II. Research bulletin. UB, Mongolia. 2008. p. 129

[19] Aristotel, Politcts. Translated by Dash-Yondon B. UB, Mongolia. Admon LLC. 2006. pp.118-119

[20] State Policy Analysis Institute. Institute of Philosophy, MAS. Research finding report. //The survey was conducted by the 17 aimags and 9 districts such involved with 5801 youth aged 18-35//. UB, Mongolia. 2016.

[21] Enkhbold D., The present status of the socio-political participation for Youth of Mongolia. IPSL, MAS. "Philosophy, legal studies-XXV" Tomus. UB, Mongolia. Tod bichig LLC. 2010. pp. 107-121

[22] Chuluunbaatar G., Khatanbold O. Representative democracy: some problems of the theory and concept. Academic article. Institute of Philosophy, MAS. "Philosophy, legal studies-XXIX" Tomus. UB, Mongolia. Tod bichig LLC. 2014. pp. 142-163

[23] Khatanbold O., Enkhbold D. Public participation in the democratic society. Social Problems in the Developing Countries. International Conference Anthology. IPSL, MAS. UB. 2013. p. 18

[24] Policy Analysis Center at the State Great Khural of Mongolia. Policy analysis - II. Academic journal. UB, Mongolia. 2008.

\section{Cited research sources}

* Between 1987-1988, the Institute of Philosophy were conducted sociological survey in accordance with targeting to research of youth education and activities in the social life.

* Governance Research Team. IPSL, MAS. State Policy Analysis Institute (NGO) has conducted joint sociological research titled on "Mongolian Youth: perception and understanding of democracy and political participation" in December 1, 2013 - March 25, 2014 including representatives of the territorial zone Zavkhan (3 soums) and Arkhangai (3soums), Darkhan-Uul (3 soums), South Gobi (2 soums) and Dornod (3 soums), Ulaanbaatar (6 districts). The sampling is accounted for total of 18-45 years from 1300 young people, and they were attended with open focal group discussion. The research final results and findings of qualitative survey has presented to the public dissemination in accordance with approval of UNDP sponsors dated on November 20, 2014.

* Sociological survey data analysis on the "Rural lifestyles" which is conducted by Dundgobi, Sukhbaatar, Arkhangai, Selenge and Bayan-Ulgii aimags in 2015-2016 by the Department of Sociology and Social Psychology at the Institute of Philosophy from Mongolian Academy of Sciences.

* IPSL, MAS. Social picture and behavior for Mongolian youth (in the borderline of the XX-XXI century. UB, Mongolia. 2012.

* IPSL, MAS. Research report on "Living goal and values changes in the Mongolian Youth”. UB, Mongolia, 2010.

* IPSL, MAS. Country lives in the public perception. Research comparative data analysis from the sociological survey series. UB, Mongolia, 2007. 